\title{
Correction to: Understanding of historical masonry for conservation approaches: the contribution of Prof. Luigia Binda to research advancement
}

\author{
Anna Anzani - Giuliana Cardani - Paola Condoleo • Elsa Garavaglia • \\ Antonella Saisi $\cdot$ Cristina Tedeschi $\cdot$ Claudia Tiraboschi $\cdot$ Maria Rosa Valluzzi $(\mathbb{D}$
}

Published online: 12 December 2019

(C) The Author(s) 2019

Correction to: Materials and Structures (2018) 51:140 https://doi.org/10.1617/s11527-018-1254-4

The article "Understanding of historical masonry for conservation approaches: the contribution of Prof. Luigia Binda to research advancement", written by "Anna Anzani, Giuliana Cardani, Paola Condoleo, Elsa Garavaglia, Antonella Saisi, Cristina Tedeschi, Claudia Tiraboschi, Maria Rosa Valluzzi”, was originally published electronically on the publisher's

The original article can be found online at https:// doi.org/10.1617/s11527-018-1254-4.

\footnotetext{
A. Anzani Durando 38/a, 20158 Milan, Italy

e-mail: anna.anzani@polimi.it 20133 Milan, Italy

e-mail: giuliana.cardani@polimi.it

P. Condoleo

e-mail: paola.condoleo@polimi.it

E. Garavaglia

e-mail: elsa.garavaglia@polimi.it

C. Tedeschi

e-mail: cristina.tedeschi@polimi.it
}

Department of Design, Politecnico di Milano, via

G. Cardani · P. Condoleo · E. Garavaglia - C. Tedeschi DICA, Department of Civil and Environmental Engineering, Politecnico di Milano, p.za L. da Vinci 32,
Internet portal (currently SpringerLink) on 16 October 2018 without open access.

The copyright of the article changed in December 2019 to (C) The Author(s) 2019, and the article is forthwith distributed under the terms of the Creative Commons Attribution 4.0 International License (http://creativecommons.org/licenses/by/4.0/), which permits use, duplication, adaptation, distribution and reproduction in any medium or format, as long as you give appropriate credit to the original author(s) and the source, provide a link to the Creative Commons license and indicate if changes were made.

\footnotetext{
A. Saisi

ABC, Department of Architecture, Built Environment and Construction Engineering, Politecnico di Milano, p.za L. da Vinci 32, 20133 Milan, Italy e-mail: antonella.saisi@polimi.it

C. Tiraboschi Material Testing Laboratory, Politecnico di Milano, p.za L. da Vinci 32, 20133 Milan, Italy e-mail: claudia.tiraboschi@polimi.it

M. R. Valluzzi ( $\square)$

DBC - Department of Cultural Heritage, University of Padova, P.zza Capitaniato 7, 35139 Padua, Italy e-mail: mariarosa.valluzzi@unipd.it
} 
Open Access This article is distributed under the terms of the Creative Commons Attribution 4.0 International License (http:// creativecommons.org/licenses/by/4.0/), which permits unrestricted use, distribution, and reproduction in any medium, provided you give appropriate credit to the original author(s) and the source, provide a link to the Creative Commons license, and indicate if changes were made.

Publisher's Note Springer Nature remains neutral with regard to jurisdictional claims in published maps and institutional affiliations. 